\title{
Proinflammatory profile of in vitro monocytes in the ageing is affected by lymphocytes presence
}

\author{
Karen Henriette Pinke ${ }^{1}$, Bruno Calzavara', Patricia Freitas Faria', Magda Paula Pereira do Nascimento', \\ James Venturini ${ }^{2}$ and Vanessa Soares Lara ${ }^{1 *}$
}

\begin{abstract}
Background: Aging is associated with complex and constant remodeling of the immune function, resulting in an increasing susceptibility to infection and others diseases. The infections caused by Gram-negative microorganisms, present in nursing homes and hospitals, constitute one of the most common infections in the elderly, and are mainly combated by innate immune cells. Although the functions of innate immunity seem more preserved during aging than of adaptive immune mechanisms, two systems operate in an integrated way in the body, so that injury in one part of the immune system inevitably affects the other as they are part of a defensive network. The aim of this study was to investigate the in vitro production of proinflammatory (TNF- $\alpha, I L-6, I L-1 \beta, C X C L-8$ and MCP-1) and antiinflammatory (TGF- $\beta$ and IL-10) cytokines by monocytes, stimulated or not (basal) with lipopolysaccharide, from healthy young and elderly subjects. By means of PBMCs, we also studied if cytokine profile is altered in these different patient groups, in the presence of lymphocytes, under the same experimental conditions.

Results: The monocytes from elderly presented higher basal production of TNF- $\alpha$, MCP-1 and lower of TGF- $\beta$ than young monocytes. PBMC showed similar cytokines production, irrespective age or stimulation presence. In the presence of lymphocytes, the spontaneous production of IL-10 was higher and of TGF- $\beta$ was lower than monocytes, regardless of age. After LPS-stimulation, the presence of lymphocytes resulted in increased IL-6, IL-1 $\beta, M C P-1$ and IL-10 and decreased CXCL-8 and TGF- $\beta$ in comparison to pure culture of monocytes from young patients. With age, the same differences were observed, except for CXCL-8 and TGF- $\beta$ which production was the same between monocytes and PBMC stimulated with LPS.
\end{abstract}

Conclusion: These findings reinforce the systemic state of inflamm-aging frequently reported in elderly and considered a factor of susceptibility to numerous diseases. Still, the cytokine production from just monocytes of the elderly showed alterations, while in the lymphocyte presence not, suggesting an immunomodulator role of lymphocytes on monocytes. In addition, the differences between the production patterns by LPS-stimulated PBMC between young and elderly volunteers can be related with an imbalance in response against Gram-negative bacteria in throughout life.

Keywords: Immunosenescence, Monocytes, PBMC, Cytokines, Inflamm-aging

\section{Background}

In recent decades, the number of elderly has increased considerably in comparison with young people and there is a trend towards continuing increase in the twenty-first century [1]. With these changes in life expectancy of the population, there has been increasing interest in studies related to health and quality of life during aging. Advancing age affects various cellular and biological functions,

\footnotetext{
* Correspondence: vanessa@fob.usp.br

${ }^{1}$ Department of Stomatology, Bauru School of Dentistry, University of São Paulo, Al. Dr. Octávio Pinheiro Brisola, 9-75, 17012-901, Bauru, SP, Brazil Full list of author information is available at the end of the article
}

including immune cells [2-9], mostly related to changes in the equilibrium between cell survival, proliferation and death. In vitro experiments have shown that absence of the enzyme telomerase leading to critical shortening of the protective ends of chromosomes plays a central role in human cell senescence $[10,11]$. These changes in immunosenescence are related to various impairments such as susceptibility to inflammatory, infectious and autoimmune diseases, as well as increasing rates of occurrence of malignancies [1,12-14]. Although these diseases are usually easily resolved clinically, elderly humans suffer from complications caused by the individual's altered

\section{Biomed Central}


response [1]. Much of this deterioration of immunity in elderly is related to predisposition to infectious diseases, such as caused by Gram-negative microorganisms that are frequent in nursing homes and hospital settings $[15,16]$ and mainly combated by innate immune cells. Although the functions of innate immunity appear to be more preserved during aging than the mechanisms developed by the adaptive immune system [8,17], recent evidence has shown that most innate immune functions are at least partly affected during aging [5-7,18-20]. Thus, changes related to immunosenescence could affect the defense mechanism as a whole; however, this complex process is not yet completely understood.

Mononuclear phagocytes cells compromise macrophages and their monocyte precursors and linage-committed bone marrow precursors. Both macrophages and peripheral blood monocytes exhibit morphological heterogeneity and functional plasticity [21]. Lipopolysaccharide (LPS), an endotoxin present in the cell wall of Gram-negative bacteria and widely used for immunological assay, is recognized by monocyte/macrophage CD14 receptor and tolllike receptor (TLR) 4-MD2 [22]. These molecular interactions result in the release of different active molecules in various inflammatory mechanisms including interleukin-1 (IL-1), prostaglandin E2 (PGE2) and tumor necrosis factor alpha (TNF- $\alpha$ ) $[22,23]$, which may be further amplified by lymphocytes, the main source of important cytokines such as interferon-gamma (IFN- $\gamma$ ) [24-26]. Peripheral blood mononuclear cells (PBMC) are composed by monocytes and lymphocytes and represent an important line of defense against infection [27-30]. Moreover, human PBMC culture is a classical and well-known test for evaluation of the immunological status and for mimicking changes that occur in infectious lesions and tissue remodeling and repair after inflammation [21].

During immunosenescence, the role of T lymphocytes is modified and related mainly to changes in intracellular signaling pathways [31], with decreased generation of lymphoid precursors [1,32] and their ability to proliferate [14]. With advancing age, changes in monocytes are mainly related to decline in the production of cytokines such as IL-1, and decrease in tumoricidal activity and superoxide production [33]. Whereas, monocytes from aged individuals are associated with increased levels of circulating interleukin-6 (IL-6) and TNF- $\alpha$ [34], characterizing the state called inflamm-aging, i.e., chronic systemic inflammation in the elderly [14]. This persistent proinflammatory profile results from high antigenic exposure throughout life to various microorganisms, including bacteria, which can change macromolecules such as deoxyribonucleic acid (DNA) or proteins by oxidation, acylation or glycosylation. Theses altered molecules can stimulate the innate immune response, particularly macrophages via TLRs [35].
The better understanding of the changes in immunomodulatory interplay between lymphocytes and monocytes during aging and in the cooperation between the cells in this defense process could elucidate the immune mechanisms of the elderly associated with increased susceptibility to infectious diseases, especially those caused by Gram-negative bacteria [1,14-16,36]. Therefore, this study investigated the in vitro production of cytokines TNF- $\alpha$, IL-6, IL-1 $\beta$, CXCL- 8, MCP-1, TGF- $\beta$ and IL-10 by $\mathrm{PBMC}$ and monocytes from elderly and young volunteers after LPS stimulation.

\section{Results}

Monocytes from elderly subjects spontaneously produced more TNF- $\alpha$, MCP-1 and less TGF- $\beta$ than young. The values of cytokine levels detected from monocytes or PBMC obtained from young or elderly persons were demonstrated as median, minimum, maximum and $1^{\text {th }}, 3^{\text {th }}$ quartiles (Tables 1 and 2). The main findings are schematized in Figures 1 and 2. The basal production of TNF- $\alpha$ and MCP-1 by monocytes from elderly group was higher than those derived from young individuals. However, the basal TNF- $\alpha$ production by PBMC showed a fall in elderly, becoming below than young, although without statistical difference (Tables 1 and 2). On the other hand, the TGF- $\beta$ production without stimulus by monocytes from elderly was lower than young, while this production was not detected by PBMC from all subjects (Figure 3).

Although the basal production has been different in some conditions between young and elderly subjects, LPSstimulated monocytes and PBMC from both age groups produced similar cytokines levels (Figures 1, 3 and 4).

In PBMC, LPS increased more the cytokines production than in monocytes. In the most experimental conditions, the LPS caused increase of the cytokine levels in relation to basal production, except MCP-1 and TGF- $\beta$ (Figures 3 and 4).

On the comparative analysis within age groups, in the presence of lymphocytes, the spontaneous production of IL-10 was higher and of TGF- $\beta$ was lower than that of monocytes, regardless of age. However, LPS-stimulated PBMC from young or elderly produced more IL-1 $\beta$, IL-6, MCP-1 and IL-10 than its respective monocytes (Figures 2, 3 and 4). Besides, the presence of lymphocytes under the LPS-stimulation resulted in lower production of CXCL-8 and TGF- $\beta$ in comparison to pure culture of monocytes in young but not in elderly (Figures 2, 3 and 4).

\section{Discussion}

According to the vitro results of this study addressing cytokines, the monocytes suffer changes throughout life. The spontaneous production of the TNF- $\alpha$ and MCP-1 by monocytes were increased in aged volunteers compared with those of young individuals. However, the 
Table 1 Cytokines production by monocytes or PBMC from young subjects

\begin{tabular}{|c|c|c|c|c|c|c|c|}
\hline Cytokines & Cellular type & Production type & Median & Minimum & Maximum & 1th quartile & 3th quartile \\
\hline \multirow[t]{4}{*}{ TNF- $a$} & Monocyte & Basal & 0.0 & 0.0 & 24.4 & 0.0 & 0.0 \\
\hline & & LPS & 246.6 & 34.5 & 1486.5 & 182.8 & 97.6 \\
\hline & PBMC & Basal & 2.5 & 0.0 & 19.0 & 0.0 & 10.4 \\
\hline & & LPS & 341.6 & 70.8 & 1165.8 & 270.3 & 728.7 \\
\hline \multirow[t]{4}{*}{ IL-6 } & Monocyte & Basal & 2.6 & 0.0 & 68.1 & 0.0 & 8.9 \\
\hline & & LPS & 175.8 & 50.5 & 282.0 & 138.3 & 186.1 \\
\hline & PBMC & Basal & 0.0 & 0.0 & 123.2 & 0.0 & 6.4 \\
\hline & & LPS & 139.6 & 0.0 & 266.6 & 116.7 & 218.2 \\
\hline \multirow[t]{4}{*}{ IL-1 $\beta$} & Monocyte & Basal & 0.0 & 0.0 & 0.1 & 0.0 & 0.0 \\
\hline & & LPS & 69.6 & 15.3 & 173.7 & 37.5 & 173.7 \\
\hline & PBMC & Basal & 0.0 & 0.0 & 1.0 & 0.0 & 0.0 \\
\hline & & LPS & 17.9 & 0.0 & 113.8 & 0.0 & 31.5 \\
\hline \multirow[t]{4}{*}{ CXCL-8 } & Monocyte & Basal & 173.1 & 48.7 & 288.8 & 130 & 240.1 \\
\hline & & LPS & 279.5 & 177.3 & 297.7 & 252.3 & 290.9 \\
\hline & PBMC & Basal & 144.8 & 64.0 & 215.1 & 118.6 & 185.4 \\
\hline & & LPS & 229.8 & 218.4 & 305.4 & 219.8 & 303.0 \\
\hline \multirow[t]{4}{*}{ MCP-1 } & Monocyte & Basal & 6.4 & 0.0 & 190.5 & 0.0 & 39.8 \\
\hline & & LPS & 48.2 & 0.0 & 241.2 & 0.0 & 148.4 \\
\hline & PBMC & Basal & 25.9 & 5.9 & 412.4 & 12.2 & 97.5 \\
\hline & & LPS & 85.0 & 0.0 & 415.3 & 29.1 & 172.7 \\
\hline \multirow[t]{4}{*}{ TGF- $\beta$} & Monocyte & Basal & 621.2 & 621.1 & 621.4 & 621.1 & 621.3 \\
\hline & & LPS & 621.2 & 621.0 & 621.6 & 621.1 & 621.2 \\
\hline & PBMC & Basal & 51.7 & 8.9 & 220.5 & 25.8 & 130.9 \\
\hline & & LPS & 567.2 & 110.2 & 690.5 & 223.1 & 587.9 \\
\hline \multirow[t]{4}{*}{ IL-10 } & Monocyte & Basal & 0.0 & 0.0 & 5.9 & 0.0 & 0.0 \\
\hline & & LPS & 149.3 & 33.8 & 654.8 & 55.4 & 323.8 \\
\hline & PBMC & Basal & 0.0 & 0.0 & 11.8 & 0.0 & 0.0 \\
\hline & & LPS & 129.1 & 47.0 & 274.1 & 102.7 & 195.6 \\
\hline
\end{tabular}

Values showed by median, minimum, maximum, $1^{\text {th }}$ and $3^{\text {th }}$ quartiles obtained by descriptive statistical analysis (Statsoft Software Inc. Tulsa, Ok, USA).

TGF- $\beta$ basal production was lower with senescence. These immune differences between young and aged people may represent some aspects of the complex and constant remodeling of the immune system with advancing age, and contribute with a proinflammatory profile. Among the variations already found and consistent with our results is a high TNF- $\alpha$ concentration detected in the plasma from the elderly $[2,37,38]$, which may be related to the development of acute and chronic inflammatory conditions, carcinogenesis, and autoimmune diseases [1,12-14]. Irrespective of age, the TNF- $\alpha$ dysregulation could be associated to several diseases, such as diabetes type II, rheumatoid arthritis and atherosclerosis, among others [39]. Although this change in the pro-inflammatory profile appears to represent an evolutionary programming to infections resist [40], we not found a relationship between high levels of TNF- $\alpha$ and increased protection against the Gram-negative microorganisms in elderly. MCP-1 is a chemokine that regulates the monocyte and memory $\mathrm{T}$ cells migration to sites of antigen-induced inflammation $[27,41,42]$ and is produced mainly in response to inflammatory stimulus [43-45]. Increased levels of MCP-1 in elderly have been correlated with the preservation of the memory $T$ cell population and progression of atherosclerosis [46,47]. Our findings about the increase on basal production of the MCP-1 in elderly could represent a systemic alteration in the traffic of the monocytes and the memory T cells with aging.

Unlike our findings, other studies showed higher levels of TGF- $\beta$ from macrophages with aging $[48,49]$. This cytokine have a complex and pleiotropic activity, presenting anti-inflammatory action on various cell types, like mast cells, $\mathrm{T}$ cells [50-53] and proinflammatory function on monocytes, attracting to the local aggression 
Table 2 Cytokines production by monocytes or PBMC from elderly subjects

\begin{tabular}{|c|c|c|c|c|c|c|c|}
\hline Cytokines & Cellular type & Production type & Median & Minimum & Maximum & 1th quartile & 3th quartile \\
\hline \multirow[t]{4}{*}{ TNF- $a$} & Monocyte & Basal & 0.0 & 0.0 & 253.1 & 0.0 & 98.4 \\
\hline & & LPS & 489.8 & 141.6 & 935.2 & 378.8 & 572.2 \\
\hline & PBMC & Basal & 0.0 & 0.0 & 98.4 & 0.0 & 0.0 \\
\hline & & LPS & 556.1 & 336.3 & 1425.1 & 433.0 & 694.7 \\
\hline \multirow[t]{4}{*}{ IL-6 } & Monocyte & Basal & 0.0 & 0.0 & 0.1 & 0.0 & 0.1 \\
\hline & & LPS & 363.2 & 319.8 & 391.8 & 329.4 & 389.6 \\
\hline & PBMC & Basal & 0.0 & 0.0 & 0.1 & 0.0 & 0.1 \\
\hline & & LPS & 321.1 & 246.4 & 489.4 & 283.2 & 405.8 \\
\hline \multirow[t]{4}{*}{ IL-1 $\beta$} & Monocyte & Basal & 0.3 & 0.0 & 6.8 & 0.0 & 3.7 \\
\hline & & LPS & 332.5 & 276.1 & 362.3 & 293.3 & 358.3 \\
\hline & PBMC & Basal & 0.0 & 0.0 & 12.3 & 0.0 & 6.1 \\
\hline & & LPS & 323.0 & 280.0 & 336.7 & 299.9 & 331.4 \\
\hline \multirow[t]{4}{*}{ CXCL-8 } & Monocyte & Basal & 59.5 & 9.3 & 213.2 & 11.8 & 158.9 \\
\hline & & LPS & 202.8 & 191.1 & 219.6 & 193.3 & 214.8 \\
\hline & PBMC & Basal & 160.1 & 16.7 & 197.5 & 82.3 & 184.9 \\
\hline & & LPS & 206.5 & 200.6 & 224.5 & 200.7 & 218.4 \\
\hline \multirow[t]{4}{*}{ MCP-1 } & Monocyte & Basal & 4.6 & 0.0 & 125.1 & 0.0 & 125.1 \\
\hline & & LPS & 999.6 & 988.0 & 1039.2 & 988.0 & 1039.2 \\
\hline & PBMC & Basal & 314.8 & 85.2 & 362.3 & 85.2 & 362.3 \\
\hline & & LPS & 994.4 & 948.2 & 1013.4 & 948.2 & 1013.4 \\
\hline \multirow[t]{4}{*}{ TGF- $\beta$} & Monocyte & Basal & 0.0 & 0.0 & 0.1 & 0.0 & 0.1 \\
\hline & & LPS & 23.3 & 0.0 & 78.6 & 0.0 & 62.6 \\
\hline & PBMC & Basal & 0.0 & 0.0 & 0.1 & 0.0 & 0.1 \\
\hline & & LPS & 117.0 & 0.0 & 397.8 & 0.0 & 315.9 \\
\hline \multirow[t]{4}{*}{ IL-10 } & Monocyte & Basal & 24.6 & 0.0 & 358.6 & 0.0 & 271.2 \\
\hline & & LPS & 903.4 & 447.2 & 3115.4 & 701.3 & 1044.9 \\
\hline & PBMC & Basal & 28.1 & 0.0 & 508.2 & 12.2 & 52.4 \\
\hline & & LPS & 966.8 & 490.3 & 1139.2 & 649.8 & 1031.2 \\
\hline
\end{tabular}

and inducing the release of IL- 1 and IL- 6 by these cells $[50,54]$.

Taken together, these results about spontaneous production of cytokines, obtained from elderly subjects corroborate the state of inflamm-aging reported in others works [55-57], which appears to predispose elderly persons to diseases such as Alzheimer's, angina and osteoporosis [58-60]. Besides, it could alter the defense mechanisms against microorganisms $[57,61]$ and reduce the ability to provide the immediate response to pathogens, as well as integrate and influence the acquired immune response [61].

Regarding PBMC, our analyzes showed no significant difference between the basal production of cytokines by elderly in relation to young. Already in stimulatedconditions, PBMC produced higher levels of IL-1 $\beta$, IL- 6 , MCP-1 and IL-10 than matched monocytes, irrespective of age. However, CXCL- 8 and TGF- $\beta$ production from stimulated PBMC was lower than matched monocytes just in young group. Some trends involving these production patterns in elderly also can be highlighted. The lymphocytes seem to increase the TNF- $\alpha$ and MCP-1 spontaneous production in the elderly, but not in young. Besides, PBMC from young tend to produce more MCP1 and less CXCL-8, whereas in advance of age, these cells seem to produce more TNF- $\alpha$ and TGF- $\beta$. Thereby, our dates indicate interplay between the two cell types that may have altered the production of cytokines from monocytes, suggesting an immunomodulador role of lymphocytes on monocytes. Also, the modified production pattern after LPS stimulus in the presence of the lymphocytes can indicate a different modulation in the elderly than in the young, under infectious conditions caused by Gram-negatives. 


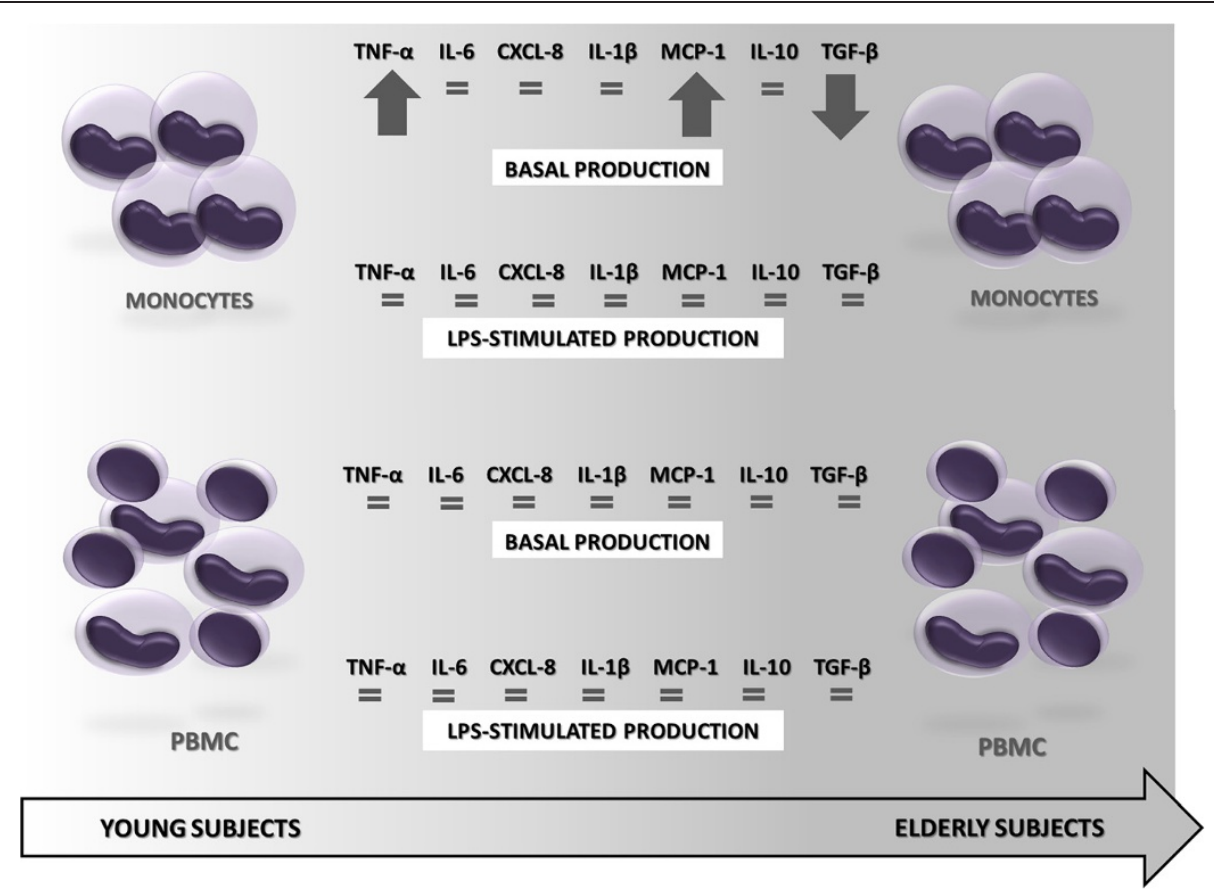

Figure 1 Main differences between the cytokines production by monocytes and PBMC from elderly subjects in relation to young. With increasing age, monocytes showed higher basal production of TNF- $a$, MCP-1 and lower of TGF- $\beta$ than monocytes from young.

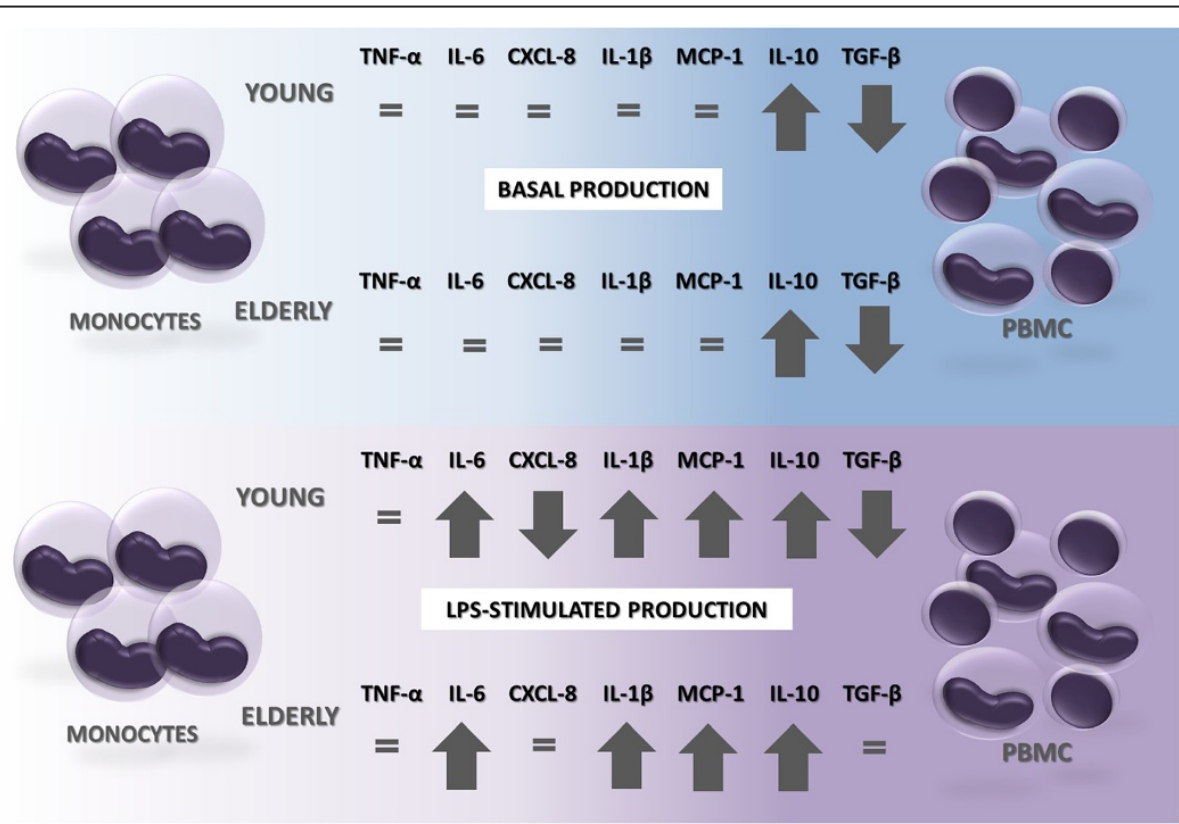

Figure 2 Influence of lymphocytes presence on cytokines production. Note that with the presence of lymphocytes the spontaneous production of IL-10 was higher and of TGF- $\beta$ was lower than that of monocytes, regardless of age. After stimulation with LPS, the presence of lymphocytes resulted in increased IL-6, IL-1 $\beta$, MCP-1 and IL-10 and decreased CXCL-8 and TGF- $\beta$ in comparison to pure culture of monocytes from of young patients. With age, the same differences were observed, except for CXCL-8 and TGF- $\beta$ which production was the same between monocytes and PBMC stimulated with LPS. 


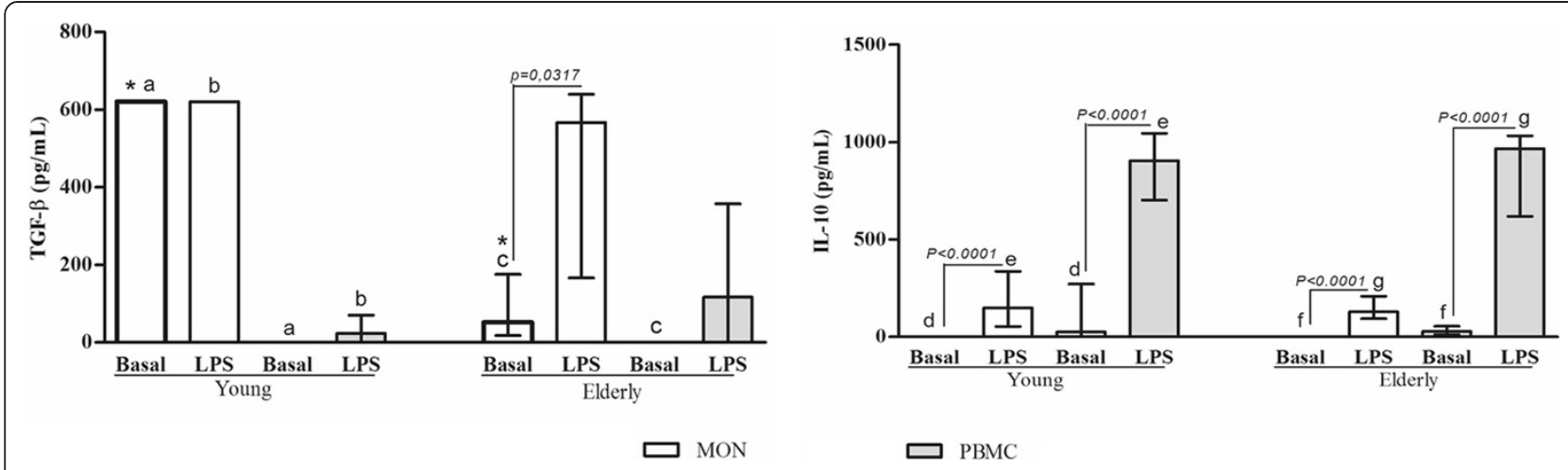

Figure 3 Measurements of the anti-inflammatory cytokines production by blood monocytes (MON) or PBMC from healthy elderly and young subjects. Peripheral blood was obtained from volunteers, and the cells were purified as described in the Material and Methods section. Monocytes and PBMC were challenged with LPS (100 ng/mL), or not (Basal), for 18 and 24 hours, respectively, and cytokine production was determined by ELISA. Columns represent the median and error bar the interquartile range. The results were evaluated by Mann-Whitney Rank Sum Test. In the same subject group, statistical differences are represented by continuous lines (cells stimulated or not) and letters for different cell types. Asterisks indicate statistical difference between groups of subjects ( $p$ values $-{ }^{*} 0,0016 ;{ }^{a}$ and b 0,$0039 ;{ }^{c} 0,0159 ;{ }^{d} 0,0010,{ }^{e}, f$ and $g$ e. $<0001$ ).

These changes may be related to changes already characterized in lymphocytes with aging. Among them is the variation in lymphocyte population in PBMC. Whereas PBMC from young subjects presents $40,6 \%$ of the naïve, $36,6 \%$ of the memory and $16,8 \%$ of the effector/cytotoxic $\mathrm{T}$ cells, in elderly, the lymphocyte population more numerous is of the memory CD8+ T cells (54\%) with great reduction on naïve $\mathrm{T}$ cells population $(3,6 \%),[62,63]$. Thus, despite the phenomena of immunosenescence being more related to the cells of the specific immunity system $[8,17]$, the findings of the present study may represent an important change in innate immunity cells from the elderly, modulated by cells of the specific immunity system, strengthening the hypothesis that the interaction between cells is an important step affected during remodeling of the immune system in advancing age. Studies on immunosenescence have shown controversies, including a decreased production of interleukin-12 (IL-12) by the monocytes of elderly persons in comparison with those of young persons, and similar production of IL-10 by monocytes from young or elderly persons $[2,33,34,64-66]$. The results of the present study also revealed similar levels of IL-10 produced by monocytes from young and elderly persons, unlike TNF- $\alpha$. Higher IL-10 production by PBMC compared with isolated monocytes was expected, since lymphocytes are major producers of IL-10. Thus, we tend to believe that the most important alterations observed in the present study could be attributed to monocytes, particularly in the presence of interaction with lymphocytes. Other alterations in $\mathrm{T}$ cell populations in the elderly [67-69] cannot be ruled out. Further studies will be needed for better clarification of the molecular mechanisms involved in interaction process between immune cells and pathogens, in the elderly.

\section{Conclusions}

In summary, it was found that in vitro monocytes from aged volunteers spontaneously produced more TNF- $\alpha$, MCP-1 and less TGF- $\beta$ in comparison with those from young persons, corroborating the state of inflamm-aging capable of predisposing persons to numerous diseases. However, in presence of lymphocyte the cytokines levels were equal between age groups, even after LPS challenge, suggesting an immunomodulador role of lymphocytes on monocytes. Still, after LPS challenge, the pattern of cytokines production in presence of lymphocyte was different between age groups, which may suggest an imbalance in the response against Gram-negative bacteria. Thus, our data may indicate that cooperation between lymphocytes and monocytes from peripheral blood can decrease a basal state of inflammation present the elderly. However in infectious conditions, this modulation can be altered and lead to a lower monocyte recruitment, proliferation and differentiation of other cell types in elderly.

\section{Methods}

\section{Sample population}

Elderly and young adults were recruited from the Bauru School of Dentistry, University of São Paulo (USP), and enrolled in the study. Immunocompromised subjects were excluded, including individuals with human immunodeficiency virus infection (HIV), diabetes mellitus requiring medication, and those taking immunomodulating medications. Subjects who were pregnant, smokers and those under treatment with antipsychotic drugs were also excluded. This study was approved by the Ethics committee at the USP (Protocol No.100/2008, 051/2008 and 172/ 2009). Informed consent was obtained from all volunteers in compliance with Resolution 196/96 of the National 


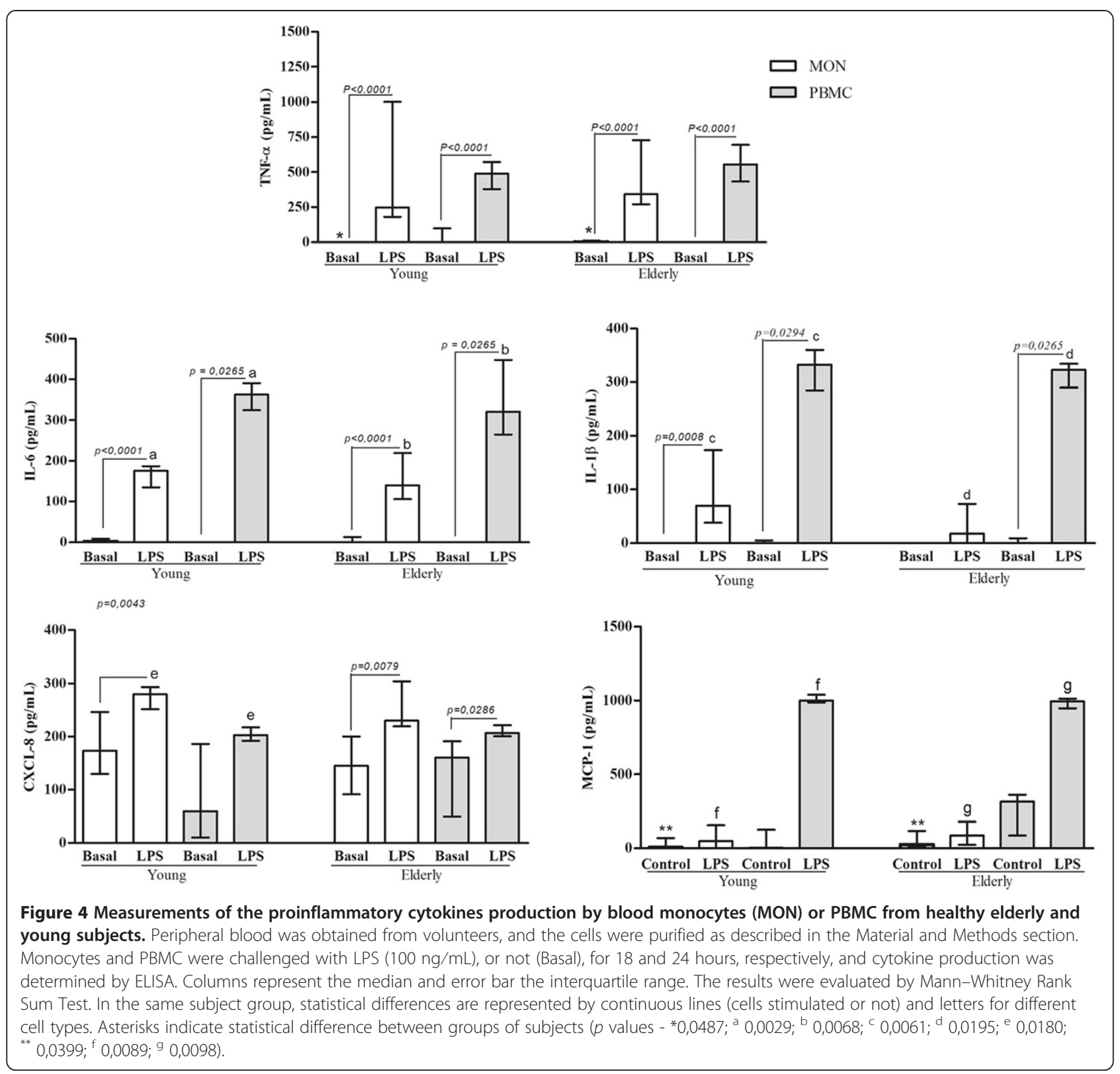

Council of Health. The inclusion criteria comprised healthy subjects in ranging from 20 to 50 years old (young) and from 60 to 85 years old (elderly) [70].

\section{PBMC isolated}

PBMC were obtained by centrifugation of heparinized venous blood over Histopaque 1083 gradients (SigmaAldrich, St. Louis, MO, USA) (400 × g for 28 minutes). The cell suspensions recovered at the interface were washed and resuspended in complete medium (RPMI 1640 supplemented with $10 \%$ heat-inactivated fetal bovine serum, $100 \mathrm{U} / \mathrm{mL}$ penicillin and $100 \mu \mathrm{g} / \mathrm{mL}$ streptomycin). Cell viability, as determined by $0.2 \%$ trypan blue dye exclusion, was $>95 \%$ in all experiments. PBMC were counted with the Türk dye staining, and suspended in complete medium at a concentration of $1 \times 10^{6} \mathrm{PBMC} / \mathrm{mL}$.

\section{Monocytes isolated}

To obtain the monocyte (MON) suspension, PBMC were isolated as previously described. The monocytes were counted using neutral red $(0.02 \%)$, and were suspended in complete medium at a concentration of $1 \times 10^{6}$ monocytes $/ \mathrm{mL}$. After this, were distributed $(1.0 \mathrm{~mL} /$ well) in 24-well plates with a flat-bottomed coverslip in each well to allow adherence of monocytes and immunofluorescence testing on the glass coverslips. After incubation for $2 \mathrm{~h}$ at $37^{\circ} \mathrm{C}$ in a humidified atmosphere of $5 \%$ $\mathrm{CO}_{2}$, non-adherent cells were removed by aspiration and 
each well was rinsed twice and resuspended in complete medium. Cell viability was assessed by morphological analysis of the cells on coverslips with marking using the anti-CD14-FITC and labeling of the cell nucleus via DAPi. Over $98 \%$ of viable cells were adherent monocytes that had intensely expressed the CD14 receptor, and were morphologically viable.

\section{Cell challenge with lipopolysaccharide (LPS)}

Monocytes and PBMC were incubated with (LPS) or without (Basal) LPS of Escherichia coli O55B5 (SigmaAldrich, St. Louis, MO, USA) (100 ng/mL - Mon; $1 \mathrm{ng} /$ $\mathrm{mL}-\mathrm{PBMC}$ ) for 18 and $24 \mathrm{~h}$, respectively, at $37^{\circ} \mathrm{C}$ in $5 \%$ $\mathrm{CO}_{2}$. Culture supernatants were harvested and stored at $-80^{\circ} \mathrm{C}$ until assayed.

\section{Quantification of cytokines}

Cytokine concentrations were determined in cell-free supernatants obtained after $24 \mathrm{~h}$ PBMC cultures and $18 \mathrm{~h}$ monocyte cultures, with or without LPS. The method utilized was enzyme-linked immunosorbent assay (ELISA), using BD OptEIA ${ }^{\text {ma }}$ kits (BD Biosciences) for TNF- $\alpha$, IL-6, IL-1 $\beta$, CXCL8, MCP-1, IL-10 and TGF- $\beta$. The evaluations were performed according to the manufacturer's instructions.

\section{Statistical methods}

All dates showed $p$ values of less than 0.05 for the Normality Test (Shapiro-Wilk) and were considered non-parametric. For statistical analysis, was utilized the Mann-Whitney Rank Sum Test with $p$ values $<0.05$ considered significant. The software Statistica 11.0 (Statsoft Software Inc. Tulsa, Ok, USA) was used.

\section{Competing interests}

The authors have no financial conflict of interests.

\section{Authors' contributions}

KHP carried out the immunoassays, assay development, data analyses, statistical analyses, and drafted the manuscript. BC participated of the immunoassays and assay development. PFF participated in the design of the study and helped with editing of the manuscript. MPPN helped to immunoassays, assay development and to draft the manuscript. JV helped in the assay development and helped to draft the manuscript. VSL conceived of the study, participated in your design and coordination and helped to draft the manuscript. All authors read and approved the final manuscript.

\section{Acknowledgements}

The authors thank Professors José Roberto Pereira Lauris and Heitor Marques Honório (Department of Pediatric Dentistry, Orthodontics and Public Health, Bauru School of Dentistry, USP) for the statistical analysis. They also thank Msc. Márcia Sirlene Zardin Graeff and Marcelo Milanda Ribeiro Lopes for their technical support and Margery Galbraith for valuable English corrections.

\section{Author details}

${ }^{1}$ Department of Stomatology, Bauru School of Dentistry, University of São Paulo, Al. Dr. Octávio Pinheiro Brisola, 9-75, 17012-901, Bauru, SP, Brazil. ${ }^{2}$ Laboratory of Experimental Immunology, Department of Biological Sciences, Faculty of Science, São Paulo State University, Av Eng Luiz Edmundo C, 14-01, 17033-360, Bauru, SP, Brazil.
Received: 14 September 2012 Accepted: 2 June 2013

Published: 8 June 2013

\section{References}

1. Ongradi J, Kovesdi V: Factors that may impact on immunosenescence: an appraisal. Immunity \& ageing: I \& A 2010, 7:7.

2. Della Bella S, Bierti L, Presicce P, Arienti R, Valenti M, Saresella M, Vergani C, Villa ML: Peripheral blood dendritic cells and monocytes are differently regulated in the elderly. Clin Immunol 2007, 122:220-228.

3. Gruver AL, Hudson LL, Sempowski GD: Immunosenescence of ageing. J Pathol 2007, 211:144-156.

4. Pawelec G, Larbi A: Immunity and ageing in man: Annual Review 2006/2007. Exp Gerontol 2008, 43:34-38.

5. Gasparoto TH, Vieira NA, Porto VC, Campanelli AP, Lara VS: Ageing exacerbates damage of systemic and salivary neutrophils from patients presenting Candida-related denture stomatitis. Immunity \& ageing: I \& A 2009, 6:3.

6. Gasparoto TH, Vieira NA, Porto VC, Campanelli AP, Lara VS: Differences between salivary and blood neutrophils from elderly and young denture wearers. J Oral Rehabil 2011, 38:41-51.

7. Gasparoto TH, de Oliveira CE, Vieira NA, Porto VC, Cunha FQ, Garlet GP Campanelli AP, Lara VS: Activation pattern of neutrophils from blood of elderly individuals with Candida-related denture stomatitis. Eur $J$ Clin Microbiol Infect Dis 2012, 31:1271-1277.

8. Weiskopf D, Weinberger B, Grubeck-Loebenstein B: The aging of the immune system. Transplant international: official journal of the European Society for Organ Transplantation 2009, 22:1041-1050.

9. Ciaramella A, Spalletta G, Bizzoni F, Salani F, Caltagirone C, Bossu P: Effect of age on surface molecules and cytokine expression in human dendritic cells. Cell Immunol 2011, 269:82-89.

10. Malaguarnera L, Ferlito L, Imbesi RM, Gulizia GS, Di Mauro S, Maugeri D, Malaguarnera M, Messina A: Immunosenescence: a review. Arch Gerontol Geriatr 2001, 32:1-14.

11. Rubin $\mathrm{H}$ : Promise and problems in relating cellular senescence in vitro to aging in vivo. Arch Gerontol Geriatr 2002, 34:275-286.

12. Batory G, Beregi E, Petranyi GG: Lymphocyte subpopulation changes by aging. Arch Gerontol Geriatr 1982, 1:129-142.

13. Motta M, Ferlito L, Malaguarnera L, Vinci E, Bosco S, Maugeri D, Malaguarnera M: Alterations of the lymphocytic set-up in elderly patients with cancer. Arch Gerontol Geriatr 2003, 36:7-14.

14. Agarwal S, Busse PJ: Innate and adaptive immunosenescence. Annals of allergy, asthma \& immunology: official publication of the American College of Allergy, Asthma, \& Immunology 2010, 104:183-190. quiz 190-182, 210.

15. Schneider EL: Infectious diseases in the elderly. Ann Intern Med 1983, 98:395-400

16. Crossley KB, Peterson PK. Infections in the elderly. Clinical infectious diseases: an official publication of the Infectious Diseases Society of America 1996, 22:209-215.

17. Sansoni P, Vescovini R, Fagnoni F, Biasini C, Zanni F, Zanlari L, Telera A, Lucchini $G$, Passeri $G$, Monti D, et al: The immune system in extreme longevity. Exp Gerontol 2008, 43:61-65.

18. Panda A, Arjona A, Sapey E, Bai F, Fikrig E, Montgomery RR, Lord JM, Shaw AC: Human innate immunosenescence: causes and consequences for immunity in old age. Trends Immunol 2009, 30:325-333.

19. Alper S: Model systems to the rescue: The relationship between aging and innate immunity. Communicative \& integrative biology 2010, 3:409-414.

20. Shaw AC, Joshi S, Greenwood H, Panda A, Lord JM: Aging of the innate immune system. Curr Opin Immunol 2010, 22:507-513.

21. Gordon S, Taylor PR: Monocyte and macrophage heterogeneity. Nat Rev Immunol 2005, 5:953-964.

22. Guha M, Mackman N: LPS induction of gene expression in human monocytes. Cell Signal 2001, 13:85-94.

23. Mozes T, Barath I, Gornicsar K, Grosz A, Mozes T, Gondocs C, Szephalmi P, Gaal K, Madarasz E: Deviations in circulating TNFalpha levels and TNFalpha production by mononuclear cells in healthy human populations. Mediators Inflamm 2011, 2011:972609.

24. Schroecksnadel K, Frick B, Winkler C, Fuchs D: Crucial role of interferongamma and stimulated macrophages in cardiovascular disease. Curr Vasc Pharmacol 2006, 4:205-213.

25. Smith JK, Dykes R, Douglas JE, Krishnaswamy G, Berk S: Long-term exercise and atherogenic activity of blood mononuclear cells in persons at risk of developing ischemic heart disease. JAMA 1999, 281:1722-1727. 
26. Chomarat $P$, Rissoan $M C$, Banchereau J, Miossec $P$ : Interferon gamma inhibits interleukin 10 production by monocytes. J Exp Med 1993, 177:523-527.

27. Xiong J, Kang K, Liu L, Yoshida Y, Cooper KD, Ghannoum MA: Candida albicans and Candida krusei differentially induce human blood mononuclear cell interleukin-12 and gamma interferon production. Infect Immun 2000, 68:2464-2469.

28. Seitz M, Deimann W, Gram N, Hunstein W, Gemsa D: Characterization of blood mononuclear cells of rheumatoid arthritis patients. I. Depressed lymphocyte proliferation and enhanced prostanoid release from monocytes. Clinical immunology and immunopathology 1982, 25:405-416.

29. Netea MG, Gijzen K, Coolen N, Verschueren I, Figdor C, Van der Meer JW, Torensma R, Kullberg BJ: Human dendritic cells are less potent at killing Candida albicans than both monocytes and macrophages. Microbes and infection / Institut Pasteur 2004, 6:985-989.

30. Netea MG, Sutmuller R, Hermann C, Van der Graaf CA, Van der Meer JW van Krieken JH, Hartung T, Adema G, Kullberg BJ: Toll-like receptor 2 suppresses immunity against Candida albicans through induction of IL-10 and regulatory T cells. J Immunol 2004, 172:3712-3718.

31. Hirokawa K: Age-related changes of signal transduction in T cells. Exp Gerontol 1999, 34:7-18.

32. Linton PJ, Dorshkind K: Age-related changes in lymphocyte development and function. Nat Immunol 2004, 5:133-139.

33. McLachlan JA, Serkin CD, Morrey-Clark KM, Bakouche O: Immunological functions of aged human monocytes. Pathobiology: journal of immunopathology, molecular and cellular biology 1995, 63:148-159.

34. Nyugen J, Agrawal S, Gollapudi S, Gupta S: Impaired functions of peripheral blood monocyte subpopulations in aged humans. J Clin Immunol 2010, 30:806-813.

35. Fulop T, Larbi A, Kotb R, de Angelis F, Pawelec G: Aging, immunity, and cancer. Discov Med 2011, 11:537-550.

36. Aw D, Silva $A B$, Palmer DB: Immunosenescence: emerging challenges for an ageing population. Immunology 2007, 120:435-446.

37. Paolisso G, Rizzo MR, Mazziotti G, Tagliamonte MR, Gambardella A, Rotondi M, Carella C, Giugliano D, Varricchio M, D'Onofrio F: Advancing age and insulin resistance: role of plasma tumor necrosis factor-alpha. Am J Physiol 1998, 275:E294-E299.

38. Bruunsgaard $H$, Andersen-Ranberg $K$, Jeune $B$, Pedersen AN, Skinhoj $P$, Pedersen BK: A high plasma concentration of TNF-alpha is associated with dementia in centenarians. The journals of gerontology Series A, Biological sciences and medical sciences 1999, 54:M357-M364.

39. Aggarwal BB: Signalling pathways of the TNF superfamily: a doubleedged sword. Nat Rev Immunol 2003, 3:745-756.

40. Vasto S, Candore G, Balistreri CR, Caruso M, Colonna-Romano G, Grimaldi MP, Listi F, Nuzzo D, Lio D, Caruso C: Inflammatory networks in ageing, age-related diseases and longevity. Mech Ageing Dev 2007, 128:83-91.

41. Carr MW, Roth SJ, Luther E, Rose SS, Springer TA: Monocyte chemoattractant protein 1 acts as a T-lymphocyte chemoattractant. Proc Natl Acad Sci U S A 1994, 91:3652-3656.

42. Jiang Y, Russell TR, Graves DT, Cheng H, Nong SH, Levitz SM: Monocyte chemoattractant protein 1 and interleukin-8 production in mononuclear cells stimulated by oral microorganisms. Infect Immun 1996, 64:4450-4455.

43. Tsou CL, Peters W, Si Y, Slaymaker S, Aslanian AM, Weisberg SP, Mack M, Charo IF: Critical roles for CCR2 and MCP-3 in monocyte mobilization from bone marrow and recruitment to inflammatory sites. J Clin Invest 2007, 117:902-909.

44. Jia T, Serbina NV, Brandl K, Zhong MX, Leiner IM, Charo IF, Pamer EG: Additive roles for MCP-1 and MCP-3 in CCR2-mediated recruitment of inflammatory monocytes during Listeria monocytogenes infection. J Immunol 2008, 180:6846-6853.

45. Yadav A, Saini V, Arora S: MCP-1: chemoattractant with a role beyond immunity: a review. Clinica chimica acta; international journal of clinical chemistry 2010, 411:1570-1579.

46. Mansfield AS, Nevala WK, Dronca RS, Leontovich AA, Shuster L, Markovic SN: Normal ageing is associated with an increase in Th2 cells, MCP-1 (CCL1) and RANTES (CCL5), with differences in SCD40L and PDGF-AA between sexes. Clin Exp Immunol 2012, 170:186-193.
47. Song $Y$, Shen $H$, Schenten D, Shan P, Lee PJ, Goldstein DR: Aging enhances the basal production of IL- 6 and CCL2 in vascular smooth muscle cells. Arterioscler Thromb Vasc Biol 2012, 32:103-109.

48. Jackaman C, Radley-Crabb HG, Soffe Z, Shavlakadze T, Grounds MD, Nelson DJ: Targeting macrophages rescues age-related immune deficiencies in C57BL/ 6J geriatric mice. Aging Cell 2013, 12:345-357.

49. Doyle KP, Cekanaviciute E, Mamer LE, Buckwalter MS: TGFbeta signaling in the brain increases with aging and signals to astrocytes and innate immune cells in the weeks after stroke. J Neuroinflammation 2010, 7:62.

50. Li MO, Wan YY, Sanjabi S, Robertson AK, Flavell RA: Transforming growth factor-beta regulation of immune responses. Annu Rev Immunol 2006, 24:99-146.

51. Roilides E, Anastasiou-Katsiardani A, Dimitriadou-Georgiadou A, Kadiltsoglou I, Tsaparidou S, Panteliadis C, Walsh TJ: Suppressive effects of interleukin-10 on human mononuclear phagocyte function against Candida albicans and Staphylococcus aureus. J Infect Dis 1998, 178:1734-1742.

52. Baltch AL, Smith RP, Franke MA, Ritz WJ, Michelsen PB, Bopp LH: Effects of cytokines and fluconazole on the activity of human monocytes against Candida albicans. Antimicrob Agents Chemother 2001, 45:96-104.

53. Dongari-Bagtzoglou A, Fidel PL Jr: The host cytokine responses and protective immunity in oropharyngeal candidiasis. J Dent Res 2005, 84:966-977.

54. Wahl SM, Hunt DA, Wakefield LM, McCartney-Francis N, Wahl LM, Roberts $A B$, Sporn MB: Transforming growth factor type beta induces monocyte chemotaxis and growth factor production. Proc Natl Acad Sci USA 1987, 84:5788-5792.

55. De Martinis M, Franceschi C, Monti D, Ginaldi L: Inflamm-ageing and lifelong antigenic load as major determinants of ageing rate and longevity. FEBS Lett 2005, 579:2035-2039.

56. Ginaldi L, Di Benedetto MC, De Martinis M: Osteoporosis, inflammation and ageing. Immunity \& ageing: / \& A 2005, 2:14

57. Franceschi C, Bonafe M, Valensin S, Olivieri F, De Luca M, Ottaviani E, De Benedictis G: Inflamm-aging. An evolutionary perspective on immunosenescence. Annals of the New York Academy of Sciences 2000, 908:244-254.

58. Kaplin A, Carroll KA, Cheng J, Allie R, Lyketsos CG, Calabresi P, Rosenberg PB: IL-6 release by LPS-stimulated peripheral blood mononuclear cells as a potential biomarker in Alzheimer's disease. International psychogeriatrics / IPA 2009, 21:413-414.

59. Liuzzo G, Angiolillo DJ, Buffon A, Rizzello V, Colizzi C, Ginnetti F, Biasucci LM, Maseri A: Enhanced response of blood monocytes to in vitro lipopolysaccharide-challenge in patients with recurrent unstable angina. Circulation 2001, 103:2236-2241.

60. Riancho JA, Zarrabeitia MT, Amado JA, Olmos JM, Gonzalez-Macias J: Age-related differences in cytokine secretion. Gerontology 1994 40:8-12.

61. Candore G, Caruso C, Colonna-Romano G: Inflammation, genetic background and longevity. Biogerontology 2010, 11:565-573.

62. Zanni F, Vescovini R, Biasini C, Fagnoni F, Zanlari L, Telera A, Di Pede P, Passeri G, Pedrazzoni $M$, Passeri $M$, et al: Marked increase with age of type 1 cytokines within memory and effector/cytotoxic CD8+ T cells in humans: a contribution to understand the relationship between inflammation and immunosenescence. Exp Gerontol 2003, 38:981-987.

63. Gerli R, Monti D, Bistoni O, Mazzone AM, Peri G, Cossarizza A, Di Gioacchino M, Cesarotti ME, Doni A, Mantovani A, et al: Chemokines, sTNF-Rs and SCD30 serum levels in healthy aged people and centenarians. Mech Ageing Dev 2000, 121:37-46.

64. Gon Y, Hashimoto S, Hayashi S, Koura T, Matsumoto K, Horie T: Lower serum concentrations of cytokines in elderly patients with pneumonia and the impaired production of cytokines by peripheral blood monocytes in the elderly. Clin Exp Immunol 1996, 106:120-126.

65. Bruunsgaard H, Pedersen AN, Schroll M, Skinhoj P, Pedersen BK: Impaired production of proinflammatory cytokines in response to lipopolysaccharide (LPS) stimulation in elderly humans. Clin Exp Immunol 1999, 118:235-241.

66. Sadeghi HM, Schnelle JF, Thoma JK, Nishanian P, Fahey JL: Phenotypic and functional characteristics of circulating monocytes of elderly persons. Exp Gerontol 1999, 34:959-970.

67. Stockinger B, Veldhoen M, Martin B: Th17 T cells: linking innate and adaptive immunity. Semin Immunol 2007, 19:353-361. 
68. Goronzy JJ, Lee WW, Weyand CM: Aging and T-cell diversity. Exp Gerontol 2007, 42:400-406

69. Njemini R, Lambert M, Demanet C, Mets T: The effect of aging and inflammation on heat shock protein 27 in human monocytes and lymphocytes. Exp Gerontol 2006, 41:312-319.

70. Wenisch C, Patruta S, Daxbock F, Krause R, Horl W: Effect of age on human neutrophil function. J Leukoc Biol 2000, 67:40-45.

doi:10.1186/1742-4933-10-22

Cite this article as: Pinke et al:: Proinflammatory profile of in vitro

monocytes in the ageing is affected by lymphocytes presence. Immunity \& Ageing 2013 10:22.

\section{Submit your next manuscript to BioMed Central} and take full advantage of:

- Convenient online submission

- Thorough peer review

- No space constraints or color figure charges

- Immediate publication on acceptance

- Inclusion in PubMed, CAS, Scopus and Google Scholar

- Research which is freely available for redistribution 